\title{
The Influence of War and Conflict on Infectious Disease: A Rapid Review of Historical Lessons We Have Yet to Learn
}

\author{
Krzysztof Goniewicz $^{1}{ }^{\circledR}$, Frederick M. Burkle ${ }^{2}$, Simon Horne ${ }^{3}$, Marta Borowska-Stefańska ${ }^{4}{ }^{(D}$, \\ Szymon Wiśniewski ${ }^{4}\left(\mathbb{D}\right.$ and Amir Khorram-Manesh ${ }^{5,6, *(1)}$ \\ 1 Department of Aviation Security, Military University of Aviation, 08-521 Dẹblin, Poland; \\ krzysztof.goniewicz@gmail.com \\ 2 Harvard Humanitarian Initiative, T.H. Chan School of Public Health, Harvard University, \\ Boston, MA 02115, USA; skipmd77@aol.com \\ 3 Academic Centre for Defence Healthcare Engagement, Research and Clinical Innovation, \\ Royal Centre for Defence Medicine, Birmingham B15 2WB, UK; simon.horne@nhs.net \\ 4 Faculty of Geographical Sciences, University of Łódź, 90-142 Łódź, Poland; \\ marta.borowska@geo.uni.lodz.pl (M.B.-S.); szymon.wisniewski@geo.uni.lodz.pl (S.W.) \\ 5 Department of Surgery, Institute of Clinical Sciences, Sahlgrenska Academy, Gothenburg University, \\ 41345 Gothenburg, Sweden \\ 6 Department of Research and Development, Armed Forces Center for Defense Medicine, \\ 42676 Gothenburg, Sweden \\ * Correspondence: amir.khorram-manesh@surgery.gu.se
}

Citation: Goniewicz, K.; Burkle, F.M.; Horne, S.; Borowska-Stefańska, M.; Wiśniewski, S.; Khorram-Manesh, A. The Influence of War and Conflict on Infectious Disease: A Rapid Review of Historical Lessons We Have Yet to Learn. Sustainability 2021, 13, 10783. https://doi.org/10.3390/su131910783

Academic Editor: Marc A. Rosen

Received: 5 September 2021

Accepted: 26 September 2021

Published: 28 September 2021

Publisher's Note: MDPI stays neutral with regard to jurisdictional claims in published maps and institutional affiliations.

Copyright: (c) 2021 by the authors. Licensee MDPI, Basel, Switzerland. This article is an open access article distributed under the terms and conditions of the Creative Commons Attribution (CC BY) license (https:/ / creativecommons.org/licenses/by/ $4.0 /)$.

\begin{abstract}
Armed conflicts degrade established healthcare systems, which typically manifests as a resurgence of preventable infectious diseases. While $70 \%$ of deaths globally are now from noncommunicable disease; in low-income countries, respiratory infections, diarrheal illness, malaria, tuberculosis, and HIV / AIDs are all in the top 10 causes of death. The burden of these infectious diseases is exacerbated by armed conflict, translating into even more dramatic long-term consequences. This rapid evidence review searched electronic databases in PubMed, Scopus, and Web of Science. Of 381 identified publications, 73 were included in this review. Several authors indicate that the impact of infectious diseases increases in wars and armed conflicts due to disruption to surveillance and response systems that were often poorly developed to begin with. Although the true impact of conflict on infectious disease spread is not known and requires further research, the link between them is indisputable. Current decision-making management systems are insufficient and only pass the baton to the next unwary generation.
\end{abstract}

Keywords: conflicts; wars; infectious disease; civilians; casualties; deaths; vaccinations

\section{Introduction}

Despite the absence of major international wars, conflict is still prevalent in many parts of the world, caused mainly by ethnic, cultural, and religious factors. While conflict was only the 27th most common cause of death in 2017, violence death is a major issue amongst younger people - the ninth most common cause of death for 15-49 years old globally [1]. The majority of these conflicts are located in low- and middle-income countries in Africa and the Middle East, where socio-economic and health problems are closely linked. While $70 \%$ of deaths globally are now from non-communicable diseases; in low-income countries, respiratory infections, diarrheal illness, malaria, tuberculosis, and HIV / AIDs are all in the top 10 causes of death [2]. The burden of these infectious diseases is exacerbated by armed conflict, translating into even more dramatic long-term consequences [3]. The impact of infectious diseases increases in wars and armed conflicts due to disruption to surveillance and response systems that were often poorly developed to begin with [4]. One of the major issues is the affected and disrupted infrastructure, which prevents access to healthcare for both conflict-affected and ordinary emergencies. In addition, many healthcare providers 
die during armed conflicts due to direct or indirect violence. The result is an insufficient healthcare system, incapable of conducting existing disease control programs and practices in resource-limited countries, and in insecure regions in which levels of humanitarian assistance and coordination between related agencies are extremely poor [5]. It is for this reason that war has been described as "development in reverse" [6].

Although the true impact of conflict on infectious disease spread is not known and requires further research, the link between them is indisputable [7]. The significance of infectious diseases for the military population is clear-throughout history, more soldiers have died from infectious diseases than from wounds inflicted during combat $[8,9]$. For example, during the Napoleonic Wars, infectious diseases were responsible for eight times more deaths among British soldiers than wounds suffered during fighting [10]. Furthermore, infectious diseases as the main reason or as a complication to surgical procedures were the main causes of deaths among soldiers during the Swedish-Russian war in the late 1780s [11]. While the toll on civilians of infectious disease resulting from conflict is harder to measure, there is no doubt that it is far greater still. For these reasons, infectious diseases have been referred to as the "third army" during an armed conflict [12].

In this paper, we review both the historical and current putative mechanisms whereby infectious diseases, occur, spread, and are exacerbated by conflict. We demonstrate the critical importance of investment in public health $(\mathrm{PH})$ infrastructure in fragile states and the maintenance of them in all countries, especially those experiencing chronic authoritarian rule that characteristically fail to maintain or improve their public health protections.

\section{Materials and Methods}

This review study analyzes the published literature on the impact of infectious diseases in wars and armed conflicts.

A rapid evidence review approach was used, by performing a systematic literature search, followed by a non-systematic literature review. This approach summarizes the available state-of-the-art research, even if quantitative outcome data is unavailable in the literature [13]. The study also uses content analysis to study all included articles, focusing on similarities and differences in the findings to present the tentative results [13-15]. The initially designed electronic search model used PubMed, Scopus, and Web of Science to create a list of available literature in English, using the following search string: Conflicts; Infectious Disease; Civilians; Casualties; Deaths; Vaccinations, alone or in combination. The search was limited to literature in English.

All original publications and literature reviews were included. Proceedings, editorials, meeting notes, news, abstracts, and non-relevant papers were excluded. A qualitative analysis of the included literature was performed (Figure 1). 


\section{Identification of studies via databases and registers}

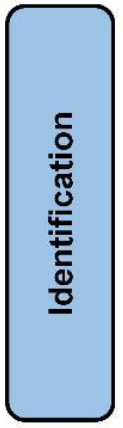

Records identified from PubMed:

Databases $(n=121)$

Records identified from Scopus:

Databases $(n=88)$

Records identified from Web of Sci-

ence: Databases $(n=172)$

Records removed before screening:

Duplicate records $(n=69)$

Records marked as ineligible by automa-

tion tools $(\mathrm{n}=32)$

Records removed for other reasons $(n=3)$

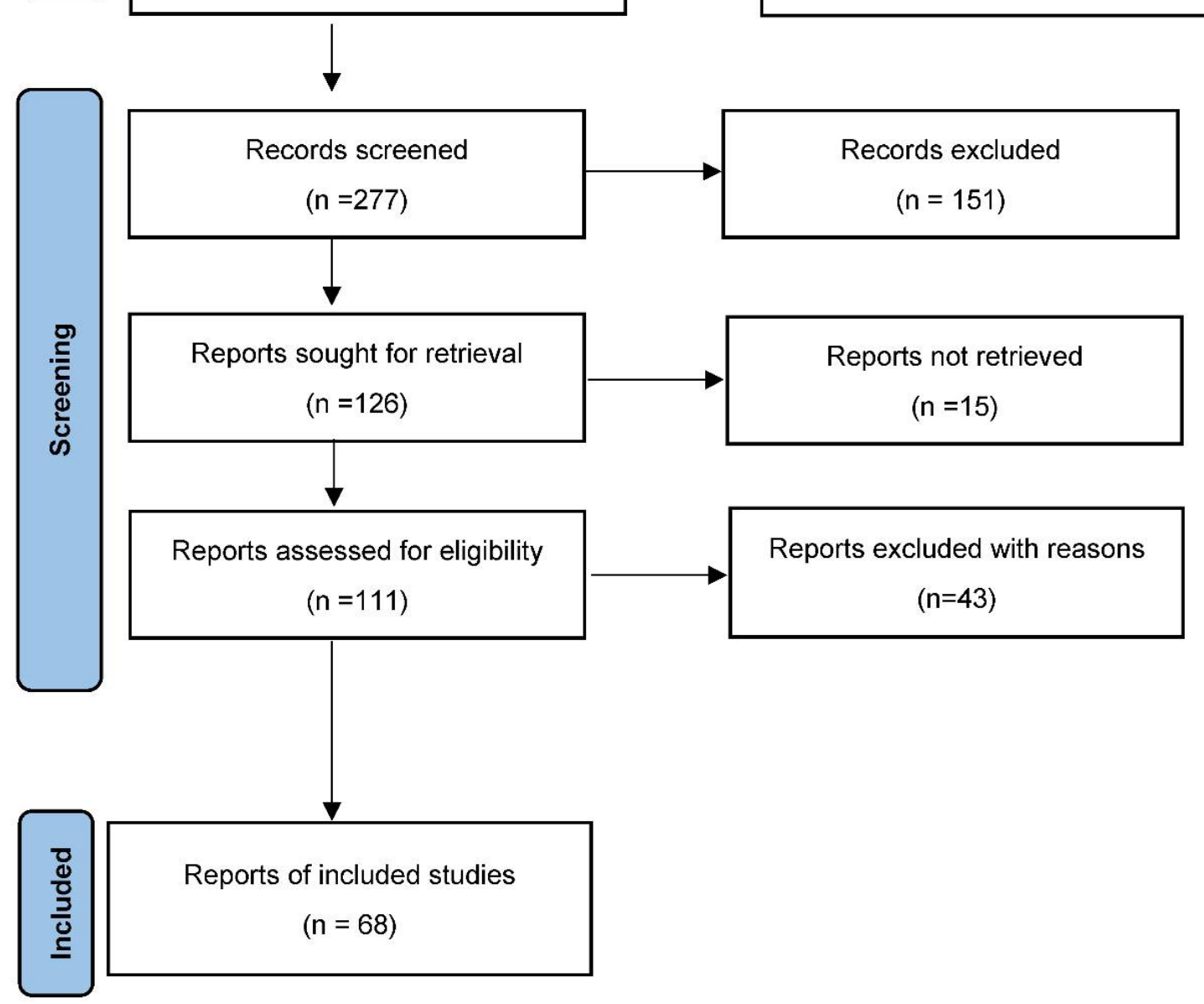

Figure 1. Flow diagram of included records for this study.

\section{Results}

The results of the search are shown in Figure 1 as a flowchart [14]. The final number of included studies were 68. All information were categorized and qualitatively evaluated. Using content analysis, the following topics were found and described below.

\subsection{Core Losses of Public Health Protections and Infrastructure as Direct Effects of War}

Armed conflicts degrade established healthcare systems, which typically manifests as a resurgence of preventable infectious diseases. In Tajikistan, malaria was effectively eradicated in the early 1960s, and from then to the early 1990s there were only 200-300 cases of the disease [10,16]. However, in 1994, during the 1992-1997 civil war, an epidemic of malaria broke out, and by 1997, there were almost 30,000 cases of the disease, although some 
estimates were as high as 200,000-500,000 [10,14-18]. Cases remained over 100,000 until 2005 [18].

Wars specifically influence prevention programs, including critical vaccination programs. The ten-year war in Sierra Leone (1991-2001) destroyed infrastructure and caused the loss of skilled workers in all sectors, including healthcare [10,19]. The war contributed to the collapse of the immunization program against tuberculosis, diphtheria, pertussis, tetanus, polio, and measles, which had been running since 1974. In 1990 at least 75\% of children aged 12 to 23 months had been fully vaccinated and this had been matched by a reduction of infant mortality rates from 162.3/1000 live births in 1985-1987 to 69.9/1000 live births in 1988-1989 [10,20,21]. At the end of the war, only half of children under the age of three had been correctly vaccinated [10]. Not only had the number of vaccinations decreased, but so had the quality - with age-inappropriate vaccinations observed in children born during the war. While the vaccination program never stopped, missing or delayed vaccinations clearly affected child health. In 2005, around 280 out of 1000 children in Sierra Leone died before their fifth birthday $[10,22]$.

The late 1990s saw a yellow fever epidemic in African countries, associated with military operations, population migrations, and vaccination program interruptions [10,23]. Cases predominantly occurred in countries affected by armed conflicts: Angola, Liberia, Sierra Leone, Ivory Coast, Guinea, and Sudan. The ability to effectively treat cases was also reduced; in Sudan in 2005, the case fatality rate for yellow fever alone was $25 \%$ [10,24].

The world polio re-education program, launched in 1988, led to an 18-fold reduction in cases. In 2001, the number of cases worldwide reached the lowest ever level-just 485 cases $[10,25]$. However, the incidence of polio started to rise again the very next year, as vaccination programs ceased in some regions, in part through political use of misinformation, and in part through conflict [26]. The long-lasting conflict in Somalia, which began in 1991 and continues to this day, also inhibited the polio re-education program $[10,27]$. Only $35 \%$ of the population was vaccinated with the required three doses of vaccine. An epidemic broke out in Mogadishu in 2005, and by September 2006, 14 out of 16 Somali regions were affected by the virus $[10,28]$.

Sudan had no cases of polio in 2001 and 2002, but in early 2003, conflict broke out again in Darfur $[10,26]$. In what has been described as one of the most severe humanitarian crises of our time, 300,000 people lost their lives and nearly 3 million fled their homes [29,30]. In 2004, the first Darfur polio case was confirmed. By January 2005, 105 cases had been reported [10,31]. In October 2013, polio cases were confirmed in Syria, which has suffered civil war since 2011, representing both the first cases in 14 years. This critically serves as a clear marker of the deteriorating state of the country's health system $[10,32]$.

\subsection{Political Attacks Delegitimizing Immunisation Programmes}

Health is seen as a tool of a legitimate government. As a result, non-state groups seeking legitimacy in fragile states are increasingly exerting influence on the dialogue around health. Unfortunately, for disease prevention measures, these interventions are often contesting the position of the established state public health system, vaccination programs being a critical target [33].

In 2002, after the lowest number of cases ever recorded worldwide, Muslim leaders from the northern provinces of Nigeria argued that the prevention program was a covert action directed by Americans against the entire African continent, and that the vaccines themselves caused infertility and transmitted HIV [34]. The vast majority of cases in Nigeria that year rose $70 \%$ [35]. The polio problem in Somalia was also clearly compounded by the decision of Al-Shabab (a fundamentalist group) to ban polio vaccines in 2013, launching a campaign to spread misinformation about the vaccine [36].

In Pakistan, the campaign against vaccinations has been particularly fierce $[10,37,38]$. The United States Central Intelligence Agency used a fake hepatitis vaccination campaign in Abottabad, Pakistan, to collect DNA to try to find the Al Qaeda leader, Osama Bin Laden [39]. The backlash against this has included violent attacks and even killings of 
medical workers [10]. Propaganda slogans proclaimed that vaccines are used to sterilize Muslims [40]. The northern part of Pakistan (the Federally Administered Tribal Areas) was the worst affected, and vaccinations there were blocked entirely [10]. This area is home to the largest number of children paralyzed by polio in Asia [41]. While the White House announced in 2014 that they would no longer use health projects to facilitate their covert activities, the damage to global trust in public health will take some time to recover [42].

\subsection{The Public Health Impact of Migration and the Resultant Conditions in Camps}

Population displacement is a common phenomenon following disasters and armed conflicts. The health needs of a displaced population, migrating often to neighboring countries with resource scarcity, and political controversies, vary widely [43]. Sociocultural and political differences may influence the given assessment, and access to and delivery of healthcare and many other helpful interventions to the displaced population [44]. Limitations in financial and material resources and existing poverty may also influence the ability of the host nations to provide humanitarian services. Consequently, these factors influence the rate of infectious diseases, among other conditions, and demand adequate social and political explanations.

As a state's public health infrastructure is normally designed to manage largely static populations, population movement immediately compromises public health support and surveillance [45]. Added to this, forced resettlement and migrations almost invariably lead to worsening housing, sanitation, and hygiene conditions for the civilians caught up in the conflict. The net result is an immediate and dramatic increase in ill health. It is estimated that in 2000 the global burden of disease in armed conflict settings was 26.1 million disability-adjusted life-years (DALYs), which accounted for $19 \%$ of the global burden of disease [46] and this is estimated to have exceeded 41.3 million now [10,47]. Armed-conflict-related infectious diseases continue to harvest lives and, according to some estimates, they will result in 41.3 million DALYs in coming years. Armed conflicts, alone, cause the highest number of displaced people in coming years [19]. It is estimated that at the end of 2012, as many as 45.1 million people were forced to resettle due to wars, of which 15.4 million received refugee status [48,49].

The civil wars in Liberia (1989-1996 and 1999-2003) and Sierra Leone (1991-2001) are an excellent case study [10]. Nearly a million inhabitants were forced to seek refuge in neighboring countries, nearly seven hundred thousand of whom entered the equally unstable Guinea [10,49]. Guinea had been plagued by threats of coups, uprisings, and revolt, and its ongoing civil war had itself aggravated the situation in neighboring Liberia and Sierra Leone $[49,50]$. Human rights violations, torture, rape, and slave labor in diamond mines contributed to a second wave of refugees, amounting to about half a million people from both countries [10,51]. These displaced populations suffered greatly from endemic and zoonotic disease, as well as reduced provision of care for non-communicable disease.

It is estimated that regardless of their location, the burden of disease in refugee camps is similar to that of the poorest developing countries [10,52-54]. Crude mortality rates may be up to 60 times higher than in peacetime [55]. Infectious diseases and malnutrition cause up to $70 \%$ of all deaths, with diarrhea, pneumonia, and malaria particularly prominent [56]. In Goma (Democratic Republic of the Congo, former Zaire), cholera and dysentery epidemics in 1994 killed 12,000 refugees from Rwanda within three weeks [10,57]. Pneumonia and malaria were responsible for almost half of the deaths in children under 5 years of age. The proportional impact of different disease categories varies around the world; in African refugee camps, the incidence of malaria tends to be higher (average 84.7/1000 per month) than in Asian camps (2.2/1000 per month). For pneumonia and diarrhea, rates were higher in Asian camps than in Africa (254.5/1000 vs. 59.2/1000 and 69.2/1000 vs. 35.5/1000, respectively) [10,58].

Mass migration of this nature increases the risk of exposure to zoonoses in several ways. First, the people may move into areas of contact with the animal hosts. This is thought to have been part of the link between Ebola and conflict [59]. As vulnerable populations flee 
their homes, their usual sources of food are no longer readily available, making bushmeat a more important part of their diet. At the same time, they may also move into forested areas for protection from armed groups who threaten them [60]. Both of these activities increase exposure to the bat reservoir and so increase the likelihood of sporadic outbreaks. Second, control of animal reservoirs may also be lost [61]. The mass population movement away from their villages allowed an explosion in the multimammate rat population around the homes they had vacated, and in the refuse around the camps. These animals are the natural reservoir for Lassa fever, and this resulted in a huge outbreak [62]. Although Lassa is an endemic disease in parts of these countries, the refugee camps were in previously unaffected areas (e.g., Kenema in Sierra Leone) $[10,63,64]$. Third, the disastrous sanitation conditions within the camps invariably lead to increased person-to-person transmission [65].

\subsection{The Public Health Response of the Foreign Aid Sector}

The essential role of public health in these situations is well-recognized. Integrated programs for the prevention of infectious diseases are very high on the list of priorities for camp management (e.g., vaccination against measles, access to clean water, and ensuring appropriate sanitary and hygienic conditions) [4]. Experience shows that implementing these actions reduces the number of preventable deaths. However, such programs will always struggle to match the impact of an established Public Health system [66].

Prolonged wars and conflicts often make the populations dependent on foreign aid. Currently, more than 30 conflict-affected countries require humanitarian aid [67]. This requirement for international support usually extends into the longer term, even after peace has been concluded, so the multi-agency humanitarian assistance must facilitate effective, efficient, and socio-culturally appropriate healthcare in a sustainable way [68]. However, it is evident that existing plans, international guidelines, and standards may only primarily provide the needed requirements for the provision of care to these groups such as medical program support, and antibiotic and malaria treatments, etc. [69]. The next step is often to increase the quality of life of the displaced population to actually prevent and mitigate the incidence of diseases [70]. Such a quality improvement cannot happen automatically and demands a well-thought-out plan, which enhances the assimilation and integration of refugees once they have reached to their new 'home' [71]. Such a plan requires robust measures, which aim at creating thoughtful prevention and education strategies to adjust the sociocultural beliefs of refugees and eradicate or mitigate popular misunderstandings and misconceptions about refugees and the whole concept of displacement [72-74].

\section{Limitations}

The presented analysis has also some limitations. The main limitation of this study is its focus on the published literature in English. Consequently, relevant information in other languages may be missing. The criteria used to narrow the selection of included publications enabled the authors to access eligible data and a feasible number of publications to handle the content analysis and to perform the review. However, the criteria used may have been too selective, resulting in missing information. These limitations can be further addressed as a part of the future research.

\section{Conclusions}

It is well-known that conflict adversely affects the health of a population. However, this relationship is complex. Direct losses include disability and death from trauma, psychological injury, and secondary disease and injury associated with gender-based sexual violence $[75,76]$. Indirect impacts include both the semi-acute surges in infectious diseases described above, but also disruption of the socio-economic aspects of a state's functionality. It would seem that the topic of war and its impact on the health of the population, as well as the occurrence of infectious diseases, fully shows the impact of the social environment on shaping the health profile of the population. Wars trigger and become promoters of infectious diseases. However, it is poor hygiene conditions, damaged 
infrastructure, the lack of and difficulty in accessing medical care, as well as the necessity of resettlement and migration, that perpetuate unfavorable conditions and indirectly translate into incidence and mortality rates $[77,78]$.

Ubiquitous violence and direct threat to life are factors that significantly limit or even make it impossible to help the victims, or to apply appropriate prophylaxis to limit the transmission of infections. The occurrence of infectious diseases in armed conflicts carries a real risk of spreading infections to other parts of the world and might be a good reason for creating a global public health system [79-81]. Therefore, international assistance is critical and vital, without which countries, often ruined by many years of wars, cannot quickly rebuild their infrastructure and medical facilities [82].

Unknown until recently are the increasing concerns of the spread of antimicrobial resistant bacteria from the Middle East conflict wounds to Europe and elsewhere [83]. The spread, first seen related to export of those wounded in conflict, is now also evident from non-conflict affected countries. It has been attributed to the "peculiar geopolitical dynamics of the area," which has experienced sustained and protracted social and political turmoil and increasing numbers of civilian wounded especially in Syria, Yemen, and Iraq [84]. Although there are "multiple pathways through which armed conflict can contribute to the creation and spread of an antibiotic resistant bacterium, the world is only beginning to experience the potential impact of these cases especially in a global environment that thrives on global travel and communication" [85].

Burkle summarized the declining public health protections within the increasingly complex global public-health environment by emphasizing: "Infectious disease outbreaks have the uncanny capacity to question the status quo, catalyze smoldering unrest, and most importantly, reveal population-based public health imperfections" [86,87]. The situation has remarkably worsened with both increasing autocratic rule and smoldering violence in many countries, as well as the worsening of infectious disease outbreaks, epidemics and pandemics, limiting the capacity and ability of all governments to recover and/or to assist each other. Burkle also claims that: "It is no longer realistic to expect the management of these gaps in infectious disease outbreaks, especially those that threaten to be epidemics and pandemics, are to be capably managed in their present state of willful denial and offenses to protect the public health by many countries" [88]. There are no exceptions. When the current pandemic occurred the World Health Organization declared that there is "no going back to normal." Only a totally new global public health infrastructure management system supported by a global public health database can possibly begin to address the immense infectious disease challenges ahead, many of which will become increasingly violent [89-92].

This historically based article reminds us, once again, that social, cultural, political, antimicrobial, economic, and environmental factors have a unique collective impact on infectious diseases. Current decision-making management systems are insufficient and only pass the baton to the next unwary generation.

Author Contributions: K.G. provided the main framework, identified primary materials, and was major contributor in writing the manuscript. A.K.-M., F.M.B., M.B.-S., S.W., and S.H. were involved in data analysis, interpretation of the results and collaborated on the writing and editing of the manuscript. All authors have read and agreed to the published version of the manuscript.

Funding: This research received no external funding.

Institutional Review Board Statement: Not applicable.

Informed Consent Statement: Not applicable.

Data Availability Statement: Not applicable.

Conflicts of Interest: The authors declare no conflict of interest. 


\section{References}

1. Rictchie, H.; Roser, M. Causes of death. Available online: https:/ / ourworldindata.org/causes-of-death (accessed on 26 March 2021).

2. World Health Organization. The Top 10 Causes of Death. Available online: https://www.who.int/news-room/fact-sheets/ detail/the-top-10-causes-of-death (accessed on 21 August 2021).

3. Justino, P. The impact of armed civil conflict on household welfare and policy responses. In Securing Peace: State-Building and Economic Development in Post-Conflict Countries; Bloomsbury Academic: London, UK, 2011; p. 19.

4. Gayer, M.; Legros, D.; Formenty, P.; Connolly, M.A. Conflict and emerging infectious diseases. Emerg. Infect. Dis. 2007, 13, 1625. [CrossRef] [PubMed]

5. Suk, J.E.; Semenza, J.C. Future infectious disease threats to Europe. Am. J. Public Health 2011, 101, 2068-2079. [CrossRef] [PubMed]

6. Shields, R.; Paulson, J. ‘Development in reverse'? A longitudinal analysis of armed conflict, fragility and school enrolment. Comp. Educ. 2015, 51, 212-230. [CrossRef]

7. McMichael, C. Climate change-related migration and infectious disease. Virulence 2015, 6, 548-553. [CrossRef] [PubMed]

8. Goniewicz, M. Effect of military conflicts on the formation of emergency medical services systems worldwide. Acad. Emergy Med. 2013, 20, 507-513. [CrossRef]

9. Fazal, T.M. Dead wrong?: Battle deaths, military medicine, and exaggerated reports of war's demise. Int. Secur. 2014, 39, 95-125. [CrossRef]

10. Wypych-Ślusarska, A.; Głogowska-Gruszka, A.; Kasznia-Kocot, J.; Malinowska-Borowska, J. Choroby zakaźne w sytuacjach kryzysowych. Część I. Konflikty zbrojne. Hygeia 2014, 49, 181-185.

11. McRae, K.D.; Helander, M.; Luoma, S. Conflict and Compromise in Multilingual Societies: Finland; Wilfrid Laurier University Press: Waterloo, ON, Canada, 1999.

12. Sartin, J.S. Infectious diseases during the Civil War: The triumph of the "Third Army". Clin. Infect. Dis. 1993, 16, 580-584. [CrossRef]

13. Haby, M.M.; Chapman, E.; Clark, R.; Barreto, J.; Reveiz, L.; Lavis, J.N. What are the best methodologies for rapid reviews of the research evidence for evidence-informed decision making in health policy and practice: A rapid review. Health Res. Policy Syst. 2016, 14, 83. [CrossRef]

14. Moher, D.; Liberati, A.; Tetzlaff, J.; Altman, D.G.; Prisma Group. Preferred reporting items for systematic reviews and metaanalyses: The PRISMA statement. PLoS Med. 2009, 6, e1000097. [CrossRef]

15. Kyngäs, H. Inductive content analysis. In The Application of Content Analysis in Nursing Science Research; Springer: Cham, Switzerland, 2020; pp. 13-21.

16. Matthys, B.; Sherkanov, T.; Karimov, S.S.; Khabirov, Z.; Mostowlansky, T.; Utzinger, J.; Wyss, K. History of malaria control in Tajikistan and rapid malaria appraisal in an agro-ecological setting. Malar. J. 2008, 7, 217. [CrossRef]

17. Aliev, S.P. Malaria in the Republic of Tajikistan. Meditsinskaia Parazitol. i Parazit. Bolezn. 2000, 2, $27-29$.

18. Rebholz, C.E.; Michel, A.J.; Maselli, D.A.; Saipphudin, K.; Wyss, K. Frequency of malaria and glucose-6-phosphate dehydrogenase deficiency in Tajikistan. Malar. J. 2006, 5, 51. [CrossRef] [PubMed]

19. Bretherton, D.; Weston, J.; Zbar, V. Peace education in a post-conflict environment: The case of Sierra Leone. Educ. Links 2003, 66, 36-41.

20. Richards, P. To fight or to farm? Agrarian dimensions of the Mano River conflicts (Liberia and Sierra Leone). Afr. Aff. 2005, 104, 571-590. [CrossRef]

21. Levitt, J. Humanitarian intervention by regional actors in internal conflicts: The cases of ECOWAS in Liberia and Sierra Leone. Temp. Int'l Comp. LJ. 1998, 12, 333. [CrossRef]

22. Baker, B.; May, R. Reconstructing Sierra Leone. Commonw. Comp. Polit. 2004, 42, 35-60. [CrossRef]

23. Kalipeni, E.; Oppong, J. The refugee crisis in Africa and implications for health and disease: A political ecology approach. Soc. Sci. Med. 1998, 46, 1637-1653. [CrossRef]

24. Jean, K.; Hamlet, A.; Benzler, J.; Cibrelus, L.; Gaythorpe, K.A.; Sall, A.; Ferguson, N.M.; Garske, T. Eliminating yellow fever epidemics in Africa: Vaccine demand forecast and impact modelling. PLoS Negl. Trop. Dis. 2020, 14, e0008304. [CrossRef] [PubMed]

25. Aylward, B.; Tangermann, R. The global polio eradication initiative: Lessons learned and prospects for success. Vaccine 2011, 29, D80-D85. [CrossRef]

26. Razum, O.; Müller, O. Polio eradication: Where are we now? Lancet 2013, 382, 1979. [CrossRef]

27. The Lancet editorial Team. Polio eradication: The CIA and their unintended victims. Lancet 2014, 383, 1862. [CrossRef]

28. Bower, H. MOGADISHU Arming the population against polio in Somalia. Lancet 2000, 356, 229. [CrossRef]

29. Hopkins, D.R.; Ruiz-Tiben, E.; Downs, P.; Withers, P.C.; Maguire, J.H. Dracunculiasis eradication: The final inch. Am. J. Trop. Med. Hyg. 2005, 73, 669-675. [CrossRef]

30. World Health Organization. Report of the Interim Meeting of the Technical Consultative Group (TCG) on the Global Eradication of Poliomyelitis, Geneva, 13-14 November 2002; World Health Organization: Geneva, Switzerland, 2003.

31. World Health Organization. Poliomyelitis outbreak escalates in the Sudan: Case from Sudan reported in Saudi Arabia. Wkly. Epidemiol. Rec. Relev. Épidémiol. Hebd. 2005, 80, 2-3.

32. Kennedy, J.; Michailidou, D. Civil war, contested sovereignty and the limits of global health partnerships: A case study of the Syrian polio outbreak in 2013. Health Policy Plan. 2017, 32, 690-698. [CrossRef] [PubMed] 
33. Brownson, R.C.; Fielding, J.E.; Maylahn, C.M. Evidence-based public health: A fundamental concept for public health practice. Annu. Rev. Public Health 2009, 30, 175-201. [CrossRef] [PubMed]

34. Rujumba, J.; Kwiringira, J. Interface of culture, insecurity and HIV and AIDS: Lessons from displaced communities in Pader District, Northern Uganda. Confl. Health 2010, 4, 18. [CrossRef]

35. Oyefara, J.L. Food insecurity, HIV / AIDS pandemic and sexual behaviour of female commercial sex workers in Lagos metropolis, Nigeria. SAHARA-J J. Soc. Asp. HIV/AIDS 2007, 4, 626-635. [CrossRef]

36. Kamadjeu, R.; Assegid, K.; Naouri, B.; Mirza, I.R.; Hirsi, A.; Mohammed, A.; Omer, M.; Dualle, A.H.; Mulugeta, A. Measles control and elimination in Somalia: The good, the bad, and the ugly. J. Infect. Dis. 2011, 204 (Suppl. S1), S312-S317. [CrossRef]

37. Greenwood, B. The contribution of vaccination to global health: Past, present and future. Philos. Trans. R. Soc. B Biol. Sci. 2014, 369, 20130433. [CrossRef]

38. Roul, A. The Pakistani Taliban's Campaign Against Polio Vaccination. CTC Sentin. August 2014, 7, 27.

39. Hussain, S.F.; Boyle, P.; Patel, P.; Sullivan, R. Eradicating polio in Pakistan: An analysis of the challenges and solutions to this security and health issue. Glob. Health 2016, 12, 63. [CrossRef] [PubMed]

40. Kennedy, J. How drone strikes and a fake vaccination program have inhibited polio eradication in Pakistan: An analysis of national level data. Int. J. Health Serv. 2017, 47, 807-825. [CrossRef]

41. Shah, S.Z.; Saad, M.; Khattak, M.H.; Rizwan, M.; Haidari, A.; Idrees, F. Why we could not eradicate polio from pakistan and how can we? J. Ayub. Med. Coll. Abbottabad 2016, 28, 423-425.

42. Chartier, Y. (Ed.) Safe Management of Wastes from Health-Care Activities; World Health Organization: Geneva, Switzerland, 2014.

43. Deola, C.; Patel, R.B. Health outcomes of crisis driven urban displacement: A conceptual framework. Disaster Health 2014, 2, 92-96. [CrossRef] [PubMed]

44. Hoddinott, P.; Allan, K.; Avenell, A.; Britten, J. Group interventions to improve health outcomes: A framework for their design and delivery. BMC Public Health 2010, 10, 800. [CrossRef]

45. Lombardo, J.S.; Buckeridge, D.L. Disease Surveillance: A Public Health Informatics Approach; John Wiley \& Sons: Hoboken, NJ, USA, 2012.

46. Murray, C.J.; Lopez, A.D.; Mathers, C.D.; Stein, C. The Global Burden of Disease 2000 Project: Aims, Methods and Data Sources; World Health Organization: Geneva, Switzerland, 2001; Volume 36, pp. 1-57.

47. Mathers, C.D.; Stein, C.; Ma Fat, D.; Rao, C.; Inoue, M.; Tomijima, N.; Bernard, C.; Lopez, A.D.; Murray, C.J. Global Burden of Disease 2000: Version 2 Methods and Results; World Health Organization: Geneva, Switzerland, 2002.

48. Mathers, C.; Smith, A.; Concha, M. Global burden of hearing loss in the year 2000. Glob. Burd. Dis. 2000, 18, 1-30.

49. Kabia, J.M. Humanitarian Intervention and Conflict Resolution in West Africa: From ECOMOG to ECOMIL; Routledge: London, UK, 2016.

50. Pigott, D.M.; Deshpande, A.; Letourneau, I.; Morozoff, C.; Reiner, R.C., Jr.; Kraemer, M.U.; Brent, S.E.; Bogoch, I.I.; Khan, K.; Biehl, M.H.; et al. Local, national, and regional viral haemorrhagic fever pandemic potential in Africa: A multistage analysis. Lancet 2017, 390, 2662-2672. [CrossRef]

51. Gberie, L. A Dirty War in West Africa: The RUF and the Destruction of Sierra Leone; Indiana University Press: Bloomington, IN, USA, 2005.

52. Cronin, A.A.; Shrestha, D.; Spiegel, P.; Gore, F.; Hering, H. Quantifying the burden of disease associated with inadequate provision of water and sanitation in selected sub-Saharan refugee camps. J. Water Health 2009, 7, 557-568. [CrossRef]

53. Hermans, M.P.; Kooistra, J.; Cannegieter, S.C.; Rosendaal, F.R.; Mook-Kanamori, D.O.; Nemeth, B. Healthcare and disease burden among refugees in long-stay refugee camps at Lesbos, Greece. Eur. J. Epidemiol. 2017, 32, 851-854. [CrossRef]

54. Kolčić, I. Double burden of malnutrition: A silent driver of double burden of disease in low-and middle-income countries. J. Glob. Health 2012, 2, 020303. [CrossRef]

55. Toole, M.J.; Waldman, R.J. Refugees and displaced persons: War, hunger, and public health. JAMA 1993, 270, 600-605. [CrossRef] [PubMed]

56. Caulfield, L.E.; de Onis, M.; Blössner, M.; Black, R.E. Undernutrition as an underlying cause of child deaths associated with diarrhea, pneumonia, malaria, and measles. Am. J. Clin. Nutr. 2004, 80, 193-198. [CrossRef]

57. Shears, P. Emerging and reemerging infections in Africa: The need for improved laboratory services and disease surveillance. Microbes Infect. 2000, 2, 489-495. [CrossRef]

58. Anyango, M.J. Water, Sanitation and Hygiene Practices as Predictors of Diarrhoea Occurrence among School Age Children in Ganze Sub County, Kenya. Ph.D. Thesis, JKUAT-COHES, Juja, Kenya. Available online: http://hdl.handle.net/123456789/5122 (accessed on 1 September 2021).

59. McPake, B.; Witter, S.; Ssali, S.; Wurie, H.; Namakula, J.; Ssengooba, F. Ebola in the context of conflict affected states and health systems: Case studies of Northern Uganda and Sierra Leone. Confl. Health 2015, 9, 23. [CrossRef] [PubMed]

60. Omoleke, S.A.; Mohammed, I.; Saidu, Y. Ebola viral disease in West Africa: A threat to global health, economy and political stability. J. Public Health Afr. 2016, 7, 534. [CrossRef] [PubMed]

61. Olivero, J.; Fa, J.E.; Real, R.; Márquez, A.L.; Farfán, M.A.; Vargas, J.M.; Gaveau, D.; Salim, M.A.; Park, D.; Suter, J.; et al. Recent loss of closed forests is associated with Ebola virus disease outbreaks. Sci. Rep. 2017, 7, 14291. [CrossRef]

62. Demby, A.H.; Inapogui, A.; Kargbo, K.; Koninga, J.; Kourouma, K.; Kanu, J.; Coulibaly, M.; Wagoner, K.D.; Ksiazek, T.G.; Peters, C.J.; et al. Lassa fever in Guinea: II. Distribution and prevalence of Lassa virus infection in small mammals. Vector Borne Zoonotic Dis. 2001, 1, 283-297. [CrossRef]

63. Andersen, K.G.; Shylakhter, I.; Tabrizi, S.; Grossman, S.R.; Happi, C.T.; Sabeti, P.C. Genome-wide scans provide evidence for positive selection of genes implicated in Lassa fever. Philos. Trans. R. Soc. B Biol. Sci. 2012, 367, 868-877. [CrossRef] 
64. Fichet-Calvet, E.; Rogers, D.J. Risk maps of Lassa fever in West Africa. PLoS Negl. Trop. Dis. 2009, 3, e388. [CrossRef] [PubMed]

65. Bariagaber, A. States, international organisations and the refugee: Reflections on the complexity of managing the refugee crisis in the Horn of Africa. J. Mod. Afr. Stud. 1999, 37, 597-619. [CrossRef]

66. Goniewicz, K.; Carlström, E.; Hertelendy, A.J.; Burkle, F.M.; Goniewicz, M.; Lasota, D.; Richmond, J.G.; Khorram-Manesh, A. Integrated healthcare and the dilemma of public health emergencies. Sustainability 2021, 13, 4517. [CrossRef]

67. Toole, M.J.; Waldman, R.J. The public health aspects of complex emergencies and refugee situations. Annu. Rev. Public Health 1997, 18, 283-312. [CrossRef]

68. Alirol, E.; Getaz, L.; Stoll, B.; Chappuis, F.; Loutan, L. Urbanisation and infectious diseases in a globalised world. Lancet Infect. Dis. 2011, 11, 131-141. [CrossRef]

69. Price-Smith, A.T. Contagion and Chaos: Disease, Ecology, and National Security in the Era of Globalization; MIT Press: Cambridge, MA, USA, 2008.

70. Khorram-Manesh, A.; Robinson, Y.; Boffard, K.; Örtenwall, P. The History of Swedish Military Healthcare System and Its Path Toward Civilian-Military Collaboration from a Total Defense Perspective. Mil. Med. 2020, 185, e1492-e1498. [CrossRef]

71. Connolly, M.A.; Gayer, M.; Ryan, M.J.; Salama, P.; Spiegel, P.; Heymann, D.L. Communicable diseases in complex emergencies: Impact and challenges. Lancet 2004, 364, 1974-1983. [CrossRef]

72. Hay, S.I.; Battle, K.E.; Pigott, D.M.; Smith, D.L.; Moyes, C.L.; Bhatt, S.; Brownstein, J.S.; Collier, N.; Myers, M.F.; George, D.B.; et al. Global mapping of infectious disease. Philos. Trans. R. Soc. B Biol. Sci. 2013, 368, 20120250. [CrossRef]

73. Thomas, S.L.; Thomas, S.D. Displacement and health. Br. Med. Bull. 2004, 69, 115-127. [CrossRef] [PubMed]

74. Spence, P.R.; Lachlan, K.A.; Burke, J.M. Adjusting to uncertainty: Coping strategies among the displaced after Hurricane Katrina. Sociol. Spectr. 2007, 27, 653-678. [CrossRef]

75. World Health Organization. Injuries and Violence: The Facts; World Health Organization: Geneva, Switzerland, 2014.

76. Kane, J.C.; Ventevogel, P.; Spiegel, P.; Bass, J.K.; Van Ommeren, M.; Tol, W.A. Mental, neurological, and substance use problems among refugees in primary health care: Analysis of the Health Information System in 90 refugee camps. BMC Med. 2014, 12, 228. [CrossRef] [PubMed]

77. Kebbede, G. Living with Urban Environmental Health Risks: The Case of Ethiopia; Routledge: London, UK, 2017.

78. Renzaho, A.M. Globalisation, Migration and Health: Challenges and Opportunities; World Scientific: Singapore, 2016.

79. Moon, S.; Røttingen, J.A.; Frenk, J. Global public goods for health: Weaknesses and opportunities in the global health system. Health Econ. Policy Law 2017, 12, 195-205. [CrossRef] [PubMed]

80. Edelstein, M.; Lee, L.M.; Herten-Crabb, A.; Heymann, D.L.; Harper, D.R. Strengthening global public health surveillance through data and benefit sharing. Emergy Infect. Dis. 2018, 24, 1324. [CrossRef]

81. What Is Global Public Health? Available online: https://www.mphonline.org/what-is-global-public-health/ (accessed on 22 September 2021).

82. Desjarlais, R.R. World Mental Health: Problems and Priorities in Low-Income Countries; Oxford University Press: Oxford, UK, 1995.

83. Weiss, R.A.; McMichael, A.J. Social and environmental risk factors in the emergence of infectious diseases. Nat. Med. 2004, 10, S70-S76. [CrossRef]

84. World Health Organization. WHO Global Strategy for Containment of Antimicrobial Resistance; World Health Organization: Geneva, Switzerland, 2001.

85. Truppa, C.; Abo-Shehada, M.N. Antimicrobial resistance among GLASS pathogens in conflict and non-conflict affected settings in the Middle East: A systematic review. BMC Infect. Dis. 2020, 20, 936. [CrossRef]

86. Burkle, F.M. Declining public health protections within autocratic regimes: Impact on global public health security, infectious disease outbreaks, epidemics, and pandemics. Prehosp. Disaster Med. 2020, 35, 237-246. [CrossRef] [PubMed]

87. Burkle, F.M.; Bradt, D.A.; Ryan, B.J. Global public health database support to population-based management of pandemics and global public health crises, part I: The concept. Prehospital Disaster Med. 2021, 36, 95-104. [CrossRef] [PubMed]

88. Burkle, F.; Bradt, D.; Green, J.; Ryan, B. Global Public Health Database Support to Population-Based Management of Pandemics and Global Public Health Crises, Part II: The Database. Prehospital Disaster Med. 2021, 36, 105-110. [CrossRef]

89. Heslop, D.A. Development and change in political systems. Political System. Encycl. Br. 2019. Available online: https: //www.britannica.com (accessed on 28 September 2021).

90. Khorram-Manesh, A.; Goniewicz, K.; Burkle, F.M.; Robinson, Y. Review of Military Casualties in Modern Conflicts-The Re-emergence of Casualties from Armored Warfare. Mil. Med. 2021. [CrossRef]

91. Khorram-Manesh, A.; Nordling, J.; Carlström, E.; Goniewicz, K.; Faccincani, R.; Burkle, F.M. A translational triage research development tool: Standardizing prehospital triage decision-making systems in mass casualty incidents. Scand. J. Trauma Resusc. Emerg. Med. 2021, 29, 119. [CrossRef] [PubMed]

92. Khorram-Manesh, A.; Burkle, F.M.; Phattharapornjaroen, P.; Ahmadi Marzaleh, M.; Sultan, M.A.; Mäntysaari, M.; Carlström, E.; Goniewicz, K.; Santamaria, E.; Comandante, J.D.; et al. The Development of Swedish Military Healthcare System: Part II-Re-evaluating the Military and Civilian Healthcare Systems in Crises through a Dialogue and Study Among Practitioners. Mil. Med. 2021, 186, e442-e450. [CrossRef] [PubMed] 